Revue bibliographique pour le domaine irano-aryen

Volume 37-38-39 | 2018

Comptes rendus des publications de 2014-2016

\title{
Alireza Askari Chaverdi, “A Stone Human Bust from Tomb-e Bot, Fars, Iran"
}

\section{Barbara Kaim}

\section{(2) OpenEdition \\ 1 Journals}

\section{Édition électronique}

URL : http://journals.openedition.org/abstractairanica/46359

DOI : 10.4000/abstractairanica.46359

ISBN : 1961-960X

ISSN : 1961-960X

Éditeur :

CNRS (UMR 7528 Mondes iraniens et indiens), Éditions de l'IFRI

Référence électronique

Barbara Kaim, « Alireza Askari Chaverdi, "A Stone Human Bust from Tomb-e Bot, Fars, Iran" », Abstracta Iranica [En ligne], Volume 37-38-39 | 2018, document 47, mis en ligne le 30 décembre 2018, consulté le 26 septembre 2020. URL : http://journals.openedition.org/abstractairanica/46359 ; DOI : https:// doi.org/10.4000/abstractairanica.46359

Ce document a été généré automatiquement le 26 septembre 2020

Tous droits réservés 


\title{
Alireza Askari Chaverdi, "A Stone Human Bust from Tomb-e Bot, Fars, Iran"
}

\author{
Barbara Kaim
}

\section{RÉFÉRENCE}

Alireza Askari Chaverdi, “A Stone Human Bust from Tomb-e Bot, Fars, Iran”, Parthica 18,2016, p. 65-71

1 L'A. analyse un buste humain en calcaire trouvé au cours de sa prospection archéologique en 2000 à Tomb-e Bot, dans le sud de la province du Fars. La technique, le style et l'iconographie de cette sculpture ont des parallèles précis dans l'art de la fin de l'époque parthe et du début de celle des Sassanides. L'A avait rapidement présenté l'ensemble des sculptures de Tomb-e Bot peu après la découverte dans Iran 40, 2002, p. 277-278. Elles sont également brièvement discutées par P. Callieri, «L'archéologie du Fars à l'époque hellénistique ", Persika 11, 2007, p. 138-141.

\section{AUTEURS}

\section{BARBARA KAIM}

Université de Varsovie 